Illinois State University

ISU ReD: Research and eData

Theses and Dissertations

$4-2-2018$

\title{
A Generational Study of Collectivism in the United States
}

Tyler Carter

Illinois State University, tylerlcarter@aol.com

Follow this and additional works at: https://ir.library.illinoisstate.edu/etd

Part of the Political Science Commons

\section{Recommended Citation}

Carter, Tyler, "A Generational Study of Collectivism in the United States" (2018). Theses and Dissertations. 847.

https://ir.library.illinoisstate.edu/etd/847

This Thesis is brought to you for free and open access by ISU ReD: Research and eData. It has been accepted for inclusion in Theses and Dissertations by an authorized administrator of ISU ReD: Research and eData. For more information, please contact ISUReD@ilstu.edu. 


\section{A GENERATIONAL STUDY OF COLLECTIVISM IN THE UNITED STATES}

\section{TYLER CARTER}

\section{Pages}

A number of past sociopolitical studies have attempted to highlight the ways in which generational identity, which develops when people come of age in different times, affects political attitudes. In this study, I investigate generational influence on the degree to which individuals embrace collectivist values, as considered by examinations of social policy attitudes and trust in government. A measure of attitudes towards social policies arguably represent collectivist values because social policy is designed to prioritize the group over the individual. A subsequent measure of trust in government augments the discussion of collectivist values because the formation of democratic political institutions occurred out of the necessity for widespread collective problem-solving. Regression analyses across the various models indicate that generation has little to no effect on collectivist values. Instead, political ideology, socioeconomic status, and sociodemographic status are more indicative of collectivist values in the United States.

KEYWORDS: collectivism; generations; institutions 


\section{A GENERATIONAL STUDY OF COLLECTIVISM IN THE UNITED STATES}

TYLER CARTER

A Thesis Submitted in Partial

Fulfillment of the Requirements

for the Degree of

MASTER OF SCIENCE

Department of Politics and Government

ILLINOIS STATE UNIVERSITY

2018 
Copyright 2018 Tyler Carter 


\title{
A GENERATIONAL STUDY OF COLLECTIVISM IN THE UNITED STATES
}

\author{
TYLER CARTER
}

COMMITTEE MEMBERS:

Carl Palmer, Chair

Meghan Leonard

T.Y. Wang 


\section{ACKNOWLEDGMENTS}

I dedicate this project to all of my colleagues, family, and friends who have listened to me incessantly talk about this research since it first began over a year ago. I would like to particularly thank the members of my committee for the amount of time they have invested in me throughout the course of my graduate studies in this department.

T.C. 


\section{CONTENTS}

Page

ACKNOWLEDGMENTS

$\begin{array}{ll}\text { TABLES } & \text { iii }\end{array}$

CHAPTER I: GENERATIONS AND POLITICS 1

$\begin{array}{ll}\text { Generations } & 2\end{array}$

$\begin{array}{ll}\text { Political Socialization } & 4\end{array}$

$\begin{array}{ll}\text { Individualism versus Collectivism } & 5\end{array}$

$\begin{array}{ll}\text { Institutional Collectivism } & 9\end{array}$

$\begin{array}{ll}\text { Theoretical Framework } & 11\end{array}$

CHAPTER II: ATTITUDES TOWARDS COLLECTIVIST POLICIES 13

$\begin{array}{ll}\text { Research Methodology } & 13\end{array}$

$\begin{array}{ll}\text { The Data } & 15\end{array}$

$\begin{array}{ll}\text { The Variables } & 15\end{array}$

$\begin{array}{ll}\text { Analysis } & 20\end{array}$

CHAPTER III: ATTITUDES TOWARDS POLITICAL INSTITUTIONS 24

$\begin{array}{ll}\text { Research Methodology } & 25\end{array}$

$\begin{array}{ll}\text { Analysis } & 26\end{array}$

CHAPTER IV: CONCLUDING REMARKS 29

$\begin{array}{ll}\text { WORKS CITED } & 31\end{array}$ 


\section{TABLES}

Table

Page

1. Cross-tabulation of Respondent Generation and Ideology

2. Ordered Logit Measuring Effects on Attitudes towards Spending on Social Policies

3. Linear Regression Measuring Effects on Trust towards Political Institutions 


\section{CHAPTER I: GENERATIONS AND POLITICS}

The American political environment has long been rife with generational conflict, which was noticeably prevalent throughout the 2016 election cycle. Tensions between older generations and younger generations manifested over a variety of mediums, including mainstream news media and social media. Not unlike previous generations, Millennials experienced explosive development in information and communications technology; however, Millennials were the first generation to grow and develop after the genesis of the Internet and the ability to access information instantaneously. Additionally, Millennials developed through their young adult lives in the midst of the largest economic collapse since the Great Depression and two wars. While previous generations were also exposed to war and recessions over the course of the $20^{\text {th }}$ Century, the development of the Information Age altered the way that younger generations in recent history were exposed to these profound events. As a result, the Millennials' worldview and the ways in which they behave may be fundamentally different than previous generations.

The conflict between the American generations is interesting to juxtapose with political attitudes. Mainstream media often labels Millennials as selfish individuals who do not care about anything but their own self-interest. Additionally, they are often charged with desiring free handouts while wanting to avoid the labor force and expecting to have everything handed to them. Despite these seemingly contrasting characterizations, younger generations may not be any of these things; rather, the differences may simply lie in the values of a particular generation. People within a society that are more communal may favor a collection of resources for collective use. Other groups may prefer to prioritize the individual, rather than the collective. In this study, I hypothesize that younger generations are moving away from an individualist society and are gravitating towards a more communal society than previous generations. 
With the increasingly evident tension between previous generations and Millennials juxtaposed with the ever-increasing polarization of the political climate in the United States, an opportunity for investigation is unveiled: Are younger American generations, specifically Millennials, more collective than past generations? Additionally, do Millennials trust political institutions more than previous generations? If not, what factors can explain differences in levels of collectivist values in America?

Generational differences in these values are important to understand because of the potential consequences for American policy. Because politics is a zero-sum game, policymakers cannot implement both individualist and collectivist policy, but they can find some compromise between the two. Many different policy areas, such as taxation, economic management, healthcare, and labor laws, are affected by the individualist/collectivist contrast. If a generation is moving towards one and away from another, the future of American policy may need to change to better adapt to, and balance, the shifting values that the upcoming generations bear.

\section{Generations}

Generation is a crucial variable in determining political identity and values. There is a distinct difference between social generation and familial generation, but I look specifically at social generation. Social generations are groups of people born within the same period of time and because I am trying to identify how similar events affect different generations, social generation is more appropriate for this study. Mannheim, who attempted to categorize American citizens based on a number of contextual factors (Mannheim 1923), heavily influenced the application of generation within social science. Historical, political, and social context are all factors that have to be accounted for when a particular group of people, or a cohort, reach an age 
of maturity that influences their collective perspective. These ages can be some kind of milestone, such as reaching adulthood. Different generations coexist within the same time and context. They live throughout the same years and witness the same events, but the different generations are at separate stages of development and therefore experience the time and events in different, subjective ways (Mannheim 1923).

Generations therefore have substantially different perspectives of their society, and consequently hold differing values. "Individuals who belong to the same generation... are endowed, to that extent, with a common location in the historical dimension of social progress" (Mannheim 1923, 290). Further studies that were based on Mannheim's conceptualization of generations assert that generational perspectives remain the same throughout the course of a person's life, indicating that they are not fluid (Whittier 1997). As a result, exposure to similar events at different times of one's life can form life-long perspectives in different ways, depending on one's stage in life, altering generational values.

One of the ways in which generational variations benefit society as a whole is that they “immortalize a mortal species" (Ryder 1965). Human beings are susceptible to death, but civilization lives on through "demographic metabolism" wherein the life and death cycles of generations creates different exposure to different events at different stages of generational development (Ryder 1965). This allows civilizations that last longer than the lives of their occupants to continue and develop based on learned lessons from past experiences. If a civilization were to contain only one immortal generation, values would remain stagnant with a uniform exposure to differing events. In order to develop and progress as a civilization, valuebased policies and actions may need to be challenged and adjusted based on contemporary 
situations. Policymakers should therefore be made aware of generational differences in values so as to best represent the society as a whole.

\section{Political Socialization}

In addition to his more general description of the manner in which generation influences social change, Ryder describes the specific effects of familial influences on individual development (1965). He asserts that familial socialization is one of the earliest stages of development for children, but adds that socialization is a continuous process throughout life and manifests itself in a number of different ways. Political socialization is the process by which a person develops their ideas about politics and their political values. One of the foundational studies of generations and political values, conducted by Jennings and Niemi, surveyed high school seniors and their parents to investigate political socialization across generations (1974). Jennings and Niemi found that parental values were quite influential on the younger family members, but that highly significant events can alter the preconceived political opinions developed from the familial influence. They assert that, while younger generations do not stray too far from previous generations, significant events can deflect upcoming generations from adapting some of the values that their parents held (1981). Niemi and Sobieszek elucidate differences between life cycle effects, period effects, and generational effects (1977). Life cycle effects are things that affect everyone as they reach a certain age, such as adult maturity. Period effects are time-based and span multiple generations, such as the consistent decline in political trust observed during the 1960s across the entire population. Finally, generational effects are unique to one generation and have lasting effects on one specific cohort as they experienced it. These effects are based on both time and events and will socialize an individual differently based 
on the individual's experience, which may alter the values that the individual adapts. Those events thus alter political socialization at a generational level, and these effects are what I am primarily concerned with in this study.

While familial influences on political socialization are notable in accordance with previous research, event-based socialization can explain the development of political attitudes across generations. Valentino and Sears posit that political socialization can occur in response to significant events (1998). More specifically, adolescent exposure to certain political events, such as presidential campaigns, have been shown to develop from political communications coming from those events. The political communication is a non-familial type of socialization for the children and adolescents that are exposed to it, and subsequently influence the values that those children gain. This evidence suggests that generations can be socialized differently as they mature based on different events. A presidential campaign in 1980, and the affiliated communication mechanisms, is different than a presidential campaign in 2016 . The variations in those events affect the developing generations differently.

\section{Individualism versus Collectivism}

Some research on generation indicates that there is a systematic, cyclical operation of generational differences (Strauss and Howe, 1997). It is possible that generations operate in a four-part cycle that repeats approximately every $80-100$ years as a saeculum. Strauss and Howe label the four parts as different turnings which last for approximately one generation each. The descriptions of the four turnings are as follows (Strauss and Howe 1997, 12):

The High: An upbeat era of strengthening institutions and weakening individualism, when a new civic order implants and the old values regime decays. 
The Awakening: A passionate era of spiritual upheaval, when the civic order comes under attack from a new values regime.

The Unraveling: A down-cast era of strengthening individualism and weakening institutions, when the old civic order decays and the new values regime implants. The Crisis: A decisive era of secular upheaval, when the values regime propels the replacement of the old civic order with a new one.

In line with Ryder's characterization of generations, these turnings enable the development of human society. "Together, the four turnings of the saeculum comprise history's seasonal rhythm of growth, maturation, entropy, and destruction" (Strauss and Howe 1997, 12). The authors posit that these cycles have operated over the last 24 generations in recent human history, but the $11^{\text {th }}$ of those 24 became the first distinctly American generation. Strauss and Howe suggest that Millennials would develop during an impending crisis, which may be the War on Terror or the 2007-2008 Recession. As a result, they should be more collective in order to come together to recover from the crisis. This assessment approaches these events as if they are generational effects, rather than period effects. For example, the recession influenced the Silent Generation, Baby Boomers, Generation X, and the Millennial Generation, but Strauss and Howe suggest that the event affected those individual generations differently. Because the event does not uniformly affect all generations in the same way, it is not a period effect. Instead, the different effects across generations would indicate that it is a generational effect. For example, Americans from both younger and older generations likely experienced financial hardship as a result of the recession, but it may have affected a younger citizen's ability to go to college or buy a house, while it may have limited an older citizen's ability to retire. While each generation is affected by the same event, the effects are different across varying generations. 
The cyclical model of generations that Strauss and Howe employ are quite different than other possible explanations. In fact, the cycle suggests that differing generational attitudes are not stagnant, in which older generations act and feel one way and younger generations feel another. Rather, the Strauss-Howe generational theory posits that the generations will maintain their individual or collective attitudes based on the time that they developed those values, and that elements of those initial values will remain intact over the course of that generation's life. This is counter to an age-effect perspective where it would be expected that as a cohort matures, they would adopt different values than when that cohort was younger and experiencing different life-cycle events.

A contrasting argument to the Strauss-Howe generational theory is that, because of intergenerational resource competition, older generations are more likely to support higher levels of taxation and spending (MacManus 1995). This is more in line with an age-effect perspective. It is argued that the opposite effect of the Strauss-Howe theory actually takes place, but for differing reasons. Self-centeredness and altruism has been commonly discussed in the discourse on generational values. Younger generations are commonly labeled as self-centered, with the suspicion that young generations want an increase in taxation and spending (MacManus 1995). Generations are often pitted against one another in a seemingly combative manner under the assumption that different generations require different resources at separate periods in time. MacManus argues and finds that older generations require more resources and as a result, are more likely to support seemingly-collective social policy that provides resources at the expense of younger generations.

The MacManus study argues that older generations are actually more supportive of increased taxation and spending because of intergenerational resource competition and their 
higher consumption of resources than younger generations, but a third theory is rooted in the fact that some studies have shown that some parts of the American population are more publicregarding than private-regarding (Wilson and Banfield 1964, 1971; Wolfinger and Field 1966). Public-regarding policy is more politically collective while private-regarding is more politically individualistic. Wilson and Banfield find that there is a difference in the support for publicregarding policies based on a number of factors. They suggest that support for public-regarding policies are more reliant upon socioeconomic and sociodemographic status. Additionally, Wolfinger and Field note ethnic differences in support for public-regarding policies as a followup to Wilson and Banfield (1966). This explanation relies on conventional wisdom which asserts that poorer people desire more spending because they receive more benefits from social programs, while richer people would oppose more spending because they would need to pay more in taxes to support those programs, while not necessarily requiring the benefits distributed by the programs in question.

In comparison to other countries, the United States is seen as an individualistic country (Triandis and Gelfand, 1998; Silvadas, Bruvold, and Nelson 2008; Chen and West 2008), but the purpose of this study is to identify if there is variation between collectivism and individualism within American generations specifically, particularly with the Millennial generation. Generation is not a phenomenon that is unique to one country. Some scholars suggest that social sciences are too narrow in their scope of investigation with regards to generations. Consequently, a global conception of generations may provide a better understanding of political and sociological interconnectedness by eliminating "methodological nationalism" from social studies that downplay the role of national interaction (Beck and Beck-Gernsheim 2009). Despite this argument, I focus on American generations for a number of reasons. First, Strauss and Howe use 
generations as their core unit of analysis in their discussion of American history. Secondly, the data available under the American National Election Survey is strictly limited to respondents from the United States. The nature of the survey data allows specific institutional questions regarding spending to be raised in order to gather information about political attitudes. I isolate American generations because of the challenge in presenting a unified international identity due to differing political context of separate nations. Finally, in light of the recent elections and the rise of populist candidates on both sides of the partisan scale, understanding contemporary American political values is imperative.

\section{Institutional Collectivism}

In an effort to elucidate the ways in which the turnings affect generational characteristics, Strauss and Howe define different archetypes that people acquire as they come of age during different historical events. The archetypes are Prophets, Nomads, Heroes, and Artists, and the descriptions of these archetypes are extensive, but the most important aspects for the purpose of this study are the generational opinions towards institutions. These archetypes are forged out of the generational cycles that Strauss and Howe describe. For example, the Hero archetype develops when a generation is born during an Unraveling and comes of age during a Crisis, as they are the ones who bear the burden of resolving whatever problems come with it. According to the archetype descriptions, Prophets and Nomads are less favorable of strong institutions while Heroes and Artists are more supportive of strengthening institutions as a result of efforts to collectively recover from Crises.

Strauss and Howe suggest that Millennials were born during the most recent Unraveling and came of age during the most recent Crisis, which may be the War on Terror and/or the 2007- 
2008 Recession. As a result, they will assume the Hero archetype, which is born during the Unraveling period, and support strengthening institutions more than the previous two generations. The Silent Generation, which assumed the Artist archetype, should be more favorable towards political institutions since they were the other living generation to have come been born during a Crisis (in their case, the Great Depression and WWII). Strauss and Howe wed these archetypes to the different turnings by suggesting that the nature of the turnings define the generations in specific, repeatable ways. Hero and Artist archetypes are always those that are born during Unravelings and Crises, respectively (Strauss and Howe 1997, 49). The events socialize them in a manner that requires them to collectively solve the problems that their individual generations face. If the Strauss-Howe generational theory is to be supported, a cycle of attitudes in favor of collectivist policy and support for institutional strength should be evident with these two generations. According to their theory, the Baby Boomers and Generation X should hold a more individualistic set of values because they lack exposure to catastrophic events that necessitate collective problem-solving. The Silent Generation and Millennial Generations should thus support collectivist policies and political institutions, while the Baby Boomers and Generation X should oppose collectivist policies and political institutions.

Generational changes in political institutions are important to investigate. Institutional strength in a democratic society is a representation of the will of the people and a direct measure of governmental power. Governmental power as expressed through bureaucratic institutional strength can create issues for agents that disagree with the agenda of the formal government in a democratic state, as they have the backing of the police and military that view the agenda as legitimate (Moe 2005). Additionally, the legitimacy of institutions enables democratic governments to act as a global power, due in part because of their ability to be recognized by 
other nations (Mansfield and Snyder 2002). Consequently, policymakers may need to understand attitudes towards political institutions as an element of international power projection. Despite Moe's ominous operation of the government, the Strauss-Howe theory discusses the strength of institutions through an individualist-collectivist framework of problem-solving (Strauss and Howe 1997). They argue that strong institutionalism comes with higher levels of collectivism, as strong institutions are indicative of a group-oriented society and result from a desire to collectively overcome a Crisis. Some scholars suggest that the relationship between collective problem solving and institutions is more about capabilities rather than strength (McDermott 2007), but Strauss and Howe specifically use the language of strength instead of general capability. In order to consolidate these differences, I use trust in the government to do what is right as a means of addressing both favorability of the government and overall capability.

\section{Theoretical Framework}

Three competing theories about collectivism, and consequently, institutions, are thus presented: First, Strauss and Howe suggest that Millennials and the Silent Generation are more collective because development through a crisis leads them to recognize that collective solutions are appropriate. Second, MacManus suggests that older generations are more positive towards taxation and spending because of limited availability of resources, and are therefore collective, but out of self-centeredness rather than altruism. Finally, Wilson and Banfield suggest that generational differences in political attitudes do not affect collectivist values. Instead, differences in socioeconomic and sociodemographic status lead citizens to be more collective.

These theories guide both studies. The first study is a direct measure of collectivist attitudes through a desire to engage in policy that is either collective or individualistic. 
A respondent who is opposed to federal spending on social programs is not likely to be supportive of a collectivist approach to problem-solving, as they are not group-oriented. The second study is a measure of the manifestation of collectivist attitudes through political institutions. Government institutions are a tool for collective problem-solving, and those who are favorable of collectivism should have higher trust in those government institutions.

In this study, I aim to identify whether or not pre-existing and competing generational theories can explain aspects of political behavior. Particularly, I aim to answer the aforementioned questions regarding generations as a whole by employing American political attitudes at the time of the most recent election. This takes two forms: first, does generation affect political attitudes towards collectivist policies? Second, does generation affect attitudes towards political institutions? Two separate analyses are conducted based on the aforementioned theoretical framework. 


\section{CHAPTER II: ATTITUDES TOWARDS COLLECTIVIST POLICIES}

The elucidation of generational differences in attitude towards certain political policies may shed some light on the ways in which historical and political context alters the fundamental values that distinct groups of people formulate and retain over the course of their lives. Measurable differences in sociopolitical values may be indicative of a generational trend in accordance with a few different previously-established theories. A more nuanced discussion about the extent to which generations vary in their preferences for collective or individualist policies may serve to ease a hotly-contested issue within contemporary political engagement, as is commonly referenced across a variety of media outlets.

\section{Research Methodology}

Social programs have long been a salient topic, both in public discourse and government policy agendas. For example, American policymakers in the $20^{\text {th }}$ Century adjusted the levels of spending on social programs several times, particularly during changes in presidential administrations. Federal spending on social programs can serve as a representation of the extent to which a population is collective or individualistic. "Collectivism was defined as a set of feelings, beliefs, behavioral intentions, and behaviors related to solidarity and concern for others" (Hui 1998). Opinion towards federal spending on social services is therefore a potential way of discerning the level of collectivism through political attitudes. Collectivists hold favorable attitudes towards sharing the burden and troubles of others and emphasize the social environment and interpersonal relationships over the individual (Bond et al. 1982; Leung and Bond 1984; Hui et al., 1991; Hui 1998; Triandis 1989). Previous studies have also demonstrated that collectivist societies are more likely to provide similar rewards for differing levels of input 
in order to maintain group harmony (Chen 1995, Leung and Bond 1984, Kim et al. 1990). Some studies have indicated that voters act irrationally by supporting public-regarding policies despite the fact that support for those policies creates a cost for them as individuals (Wilson and Banfield 1964, 1971). In line with these methods of thinking, public-regarding policies such as social services are operationalized as collectivist. Consequently, collectivists should support higher levels of spending on social services that are aimed at alleviating socioeconomic problems and promoting the general welfare of fellow citizens at the expense of their own individual benefit, regardless of whether or not those people are capable of equally contributing to the society.

Some suggest that an increase in spending on social programs elevates the overall satisfaction of life for those of lower socioeconomic status (Radcliff 2001), which is why it might be important to identify if generational differences influence the amount of spending on social services. According to the Congressional Budget Office (2017), just under $20 \%$ of the United States Gross Domestic Product is from revenue made from individual income tax, payroll tax, and corporate income tax. Given that federal spending on social services is a result of taxing individual Americans, political attitudes towards spending on social services is used as a way to operationalize collectivist attitudes for the purpose of this study. Additional support for this operationalization is that some scholars suggest that more socialist countries are more collectivist (Radcliff 2001). Socialist countries are, in part, defined by the presence of social programs, and given the collectivist focus on groups and interpersonal relationships, support for wider-reaching social programs may be interpreted as an increase in collectivism. 


\section{The Data}

In order to identify trends in American political attitudes, I use survey data from the 2016 American National Election Study. The ANES is a collection of survey questions and responses from studies that are conducted every four years during the presidential elections. The ANES sample included both face-to-face and online modes of interviews. The face-to-face sample had 1,181 pre-election respondents and 1,059 post-election respondents. The online sample had 3,090 pre-election respondents and 2,590 respondents. After dropping respondents who did not participate in both the pre-election and post-election interviews, there were 2,641 remaining respondents for the first three models which combined both the online and face-to-face interviews. All respondents were US eligible voters. This data nearly covers the full demographic range of American citizens that I want to study. The only exclusion is the tail-end of the Millennial generation that is not yet old enough to vote.

\section{The Variables}

The first dependent variable for the study is attitude towards federal spending on aid to the poor. Attitudes are measured from responses to the sentence "Government should provide many fewer/more services for aid to the poor" and ranked from 1-3. A response of "1" is the statement that government should provide many more services, while a response of " 2 " is the statement that government should provide many fewer services. The third response is that government spending should remain the same. For my study, this variable was recoded in order

to make it an ordinal scale from 1 to 3 . The first category was recoded to respondent support for a decrease in spending on aid to the poor, the second category is respondent support for a 
maintenance of current spending on aid to the poor, and the third category was recoded to be respondent support for an increase in spending on aid to the poor.

In order to expand the scope of collectivism, a second dependent variable is used in a similar model as the first. Attitudes towards federal spending on welfare programs is employed. The attitudes are measured with responses to the sentence "Government should provide more/fewer services for welfare programs" and are ranked on an ordinal scale from 1-3. A response of " 1 " is the statement that government should increase resources for welfare programs, while a response of " 3 " is the statement that government should decrease amount of resources for welfare programs. A response of " 2 " is the statement that government spending on welfare programs should remain the same. This variable was recoded in the same ordinal manner as the first, from 1 to 3, where 1 is coded as support for a decrease in spending, 2 is coded as support for maintenance of current spending, and 3 is coded as support for an increase in spending.

Finally, a third model employing attitudes towards an increase in government spending on healthcare is used. This model specifically is employed because of the nature of the resources required as a part of healthcare in order to examine if resource requirements affect generational attitudes. The variable is coded in the same way that the previous dependent variables are. A response of " 1 " is the statement that government should increase spending on healthcare, while an argument of " 3 " is the statement that government should reduce spending on healthcare.

Finally, a response of " 2 " is the statement that government spending on healthcare should remain the same. Ideally, a future study would include public higher education as a variable to demonstrate one policy area that would benefit younger generations more than older generations.

The first independent variable is age, which is recoded to identify generational differences. Although generational definitions are somewhat arbitrary, the United States Census 
Bureau and the Pew Research Center have created artificial labels for them, which will be used as the standard for this study. The Pew Research Center defines Americans born between 1928 and 1945 as the Silent Generation. The United States Census Bureau identifies B aby Boomers as anyone born from the age of 1946 through 1964. The Pew Research Center defines Generation X as anyone born between 1965 and 1980, but 1981 is included in this generation in order to accommodate the Pew Research Center's definition of Generation X and the United States Census Bureau's definition of Millennials. The U.S Census Bureau identifies Millennials as anyone born between 1982 and 2000, so 1981 was selected to reconcile the two.

The American National Election Study measures date of birth ranging from 1921 through 1997. This data was then recoded based on the above definitions of generation. Respondents who are ages $18-35$ were placed into the Millennial category. Respondents who are ages 36-52 are placed into the Generation X category1. Respondents who are 53-72 are categorized as Baby Boomers, and respondents who are ages 73 and above are categorized as the Silent Generation. Not all Millennials are of voting age and therefore were not sampled for the American National Election Survey, but given their inability to vote, it should not matter much for the sake of this study. They are cut off in the year 1997, excluding three years of the Millennial generation. Data from the upcoming 2020 American National Election Survey would push the entire Millennial generation over the minimum voting age and might offer a more accurately representative sample.

The second independent variable is ideological self-identification. This variable was measured on a seven-point scale. Partisan identification was also included, but multicollinearity was discovered with political ideology and partisan identification, so partisan identification was omitted. Respondents who answered 1, 2, or 3 for "very liberal," "somewhat liberal," or "liberal" 
were recoded and grouped together. Respondents who answered 4 were categorized as moderates. Finally, respondents who answered 5, 6, or 7 for "conservative," "somewhat conservative," or "very conservative" respectively were recoded and grouped together. The recoding of this variable flatly denotes liberal ideology, moderate ideology, and conservative ideology. Conventional wisdom indicates that political ideology is a strong indicator of preferences towards government spending, so this variable is controlled in order to more carefully identify the influence of generation on attitudes towards government-provided social services. Negative opinions of government spending would likely indicate more negative opinions towards social services and vice versa, so controlling for ideology is necessary in order to accurately isolate and reflect generational differences, if any exist. Table 1 displays a crosstabulation of generations and political ideology. This table corroborates data from the Pew Research Center which indicates that a higher percentage of Millennials are Liberal, while the older generations see a sharp increase in percentage of Conservatives (Maniam and Smith 2017).

Table 1

Cross-tabulation of Respondent Generation and Ideology

\begin{tabular}{lcccc}
\hline Generations (\%) & \multicolumn{5}{c}{ Ideology $(\%)$} \\
\cline { 2 - 5 } Millennials & Liberal & Moderate & Conservative & Total \\
\cline { 2 - 5 } & 351 & 205 & 267 & 823 \\
Generation $X$ & $(42.65)$ & $(24.91)$ & $(32.44)$ & $(100.00)$ \\
\cline { 2 - 5 } & 177 & 180 & 248 & 605 \\
Baby Boomers & $(29.26)$ & $(29.75)$ & $(40.99)$ & $(100.00)$ \\
\cline { 2 - 5 } Silent & 283 & 255 & 441 & 979 \\
Generation & $(28.91)$ & $(26.05)$ & $(45.05)$ & $(100.00)$ \\
\cline { 2 - 5 } Total & 56 & 61 & 117 & 234 \\
\cline { 2 - 5 } & $(23.93)$ & $(26.07)$ & $(50.00)$ & $(100.00)$ \\
\hline
\end{tabular}


Sociodemographic and socioeconomic status are the remaining independent variables in the study. Sex and race are included within the regression to control for sociodemographic status when isolating generations. Race has six categories: White, Black, Asian, Native American, Hispanic, and Other. Finally, income is included to identify differing generational attitudes across socioeconomic levels. Race and sex are categorical and are thus included in the regressions as factor variables. Conventional wisdom indicates that poorer people more frequently support higher spending on social programs, possibly because they are more likely to benefit from them. Wealthier people less frequently support spending on social programs, possibly because they do not benefit from them as much as low socioeconomic persons, so it is imperative to control for income levels when isolating generational effects on attitudes towards those programs.

There are a few limitations for this study that researchers may want to address in the future. In addition to a larger sample size, a dependent variable that focused on potential resources to younger generations may be advantageous. Healthcare is a one-sided policy that benefits older generations more than younger, healthier generations, so it would be more beneficial to include a dependent variable such as government-funded higher education that would place younger generations as the primary beneficiary to such policy, and the level of collectivism across different generations may or may not be apparent. Finally, the American National Election Study did not provide a variable that sufficiently explained levels of political knowledge. Assessing political knowledge with a study such as this would be beneficial, as it would reflect whether or not respondents towards increasing spending actually know that the programs and policies are costing them a certain amount of their own resources. Respondents who are more collective may be content with increasing their cost in order to benefit the group, 
but it is imperative to know if those respondents are aware of how and why government spending on social programs operates. Other methods of measuring collectivism may include an analysis of political participation, contributions to charitable organizations, or the degree to which someone holds certain family or community values that are not necessarily fiscally or politically oriented. For the aforementioned reasons, my purpose in this study is to investigate just one of the many different perspectives of collectivist values and it is not exhaustive of the entire range of its potential measurement.

\section{Analysis}

The results of generational, socioeconomic, and sociodemographic effects on collectivist values can be found in Table 2 below. The analysis indicates that generation is not significant in two of the three models. Generation was coded in several different ways to verify that the results were not a product of the coding. For example, one of these models placed Millennials and Generation X into a unified group while Baby Boomers and the Silent Generation were placed into another to more simply distinguish the younger generations from the older ones. While the quantitative results were slightly different, there was no change in the substantive results that would indicate that a respondent's generation is a significant factor in determining collectivist political values.

The outlying result from the generation variable is within the healthcare model. Baby Boomers and the Silent Generation are statistically significant in comparison to Millennials, while Generation $\mathrm{X}$ is not. This indicates that the two older generations are more supportive of increasing federal spending on healthcare. These results support the MacManus theory that older generations require more resources and are thus more supportive of higher federal spending. 
Older people require more resources for healthcare and would consequently support an increase in government funding for such program. Despite the generational difference, this is likely more so an age effect rather than a generational effect. In a similar vein, it is possible that if there was another variable, such as support for federal spending on higher education, the younger generations would be more favorable of it than older people due to the nature of such program producing an age effect.

The regression shows that ideology is a highly statistically significant factor in determining political attitudes towards social spending on collective programs. This was expected as a result of conventional wisdom that indicates a difference in the role of government based on personal political ideology. In each of the three dependent variables, ideology is significant at a lower than a .001 level when compared to moderates, which indicates that ideology plays a significant part in determining responses towards spending on these programs. In each of the three dependent variables, Black respondents and Hispanic respondents were shown to be different than White respondents at a 0.001 level. Respondents who selected "Other" for race were shown to be statistically significant in comparison to White respondents in their responses to federal spending on welfare programs and on healthcare. The former showed a significance at the .05 level and the latter showed significance at the .01 level. The substantive results were the same when other categories aside from White were selected as the base category as a factor variable. There is no statistical significance between male and female respondents in any of the models. The final independent variable is income, which is statistically significant at a .001 level across the first two models but not statistically significant in the healthcare model. In the first two models, the results show that as income increases, the respondent becomes more likely to oppose federal spending on those programs. 
Income and race are both heavily influential on attitudes towards collectivist policy while generation is not. These models demonstrate substantial support for the Wilson and Banfield theory which suggests that socioeconomic and sociodemographic status, rather than generational differences, affect levels of endorsement of collectivism in America. The Strauss-Howe generational theory and the MacManus generational theory lack support from these results. If the results of the Strauss-Howe generational theory were to be supported by this study, one would expect to see a cycle of support wherein the Silent Generation would support federal spending on collectivist programs in a manner similar to Millennials, while the Baby Boomers and Generation $\mathrm{X}$ would oppose spending. Instead, there is no significance across generations. For evidence to suggest that the MacManus generational theory holds true, the study would have to demonstrate that the older generations are more supportive of increased spending. This holds true in the healthcare model, but likely because it is an age effect and not a generational effect. 
Table 2

Ordered Logit Measuring Effects on Attitudes towards Spending on Social Policies

\begin{tabular}{|c|c|c|c|}
\hline & Aid to the Poor & Welfare Programs & Healthcare \\
\hline \multicolumn{4}{|l|}{ Generations } \\
\hline Generation X & $\begin{array}{l}-.03 \\
(.11)\end{array}$ & $\begin{array}{l}-.07 \\
(.11)\end{array}$ & $\begin{array}{l}.005 \\
(.11)\end{array}$ \\
\hline Baby Boomers & $\begin{array}{l}-.04 \\
(.09)\end{array}$ & $\begin{array}{l}-.02 \\
(.10)\end{array}$ & $\begin{array}{l}.27 * * \\
(.10)\end{array}$ \\
\hline Silent Generation & $\begin{array}{c}.04 \\
(.14)\end{array}$ & $\begin{array}{c}.08 \\
(.15)\end{array}$ & $\begin{array}{l}.40 * * \\
(.15)\end{array}$ \\
\hline \multicolumn{4}{|l|}{ Ideology } \\
\hline Liberal & $\begin{array}{c}1.11 * * * \\
(.10)\end{array}$ & $\begin{array}{c}1.31 * * * \\
(.10)\end{array}$ & $\begin{array}{c}-1.20 * * * \\
(.11)\end{array}$ \\
\hline Conservative & $\begin{array}{c}-.81 * * * \\
(.10)\end{array}$ & $\begin{array}{c}-1.1 * * * \\
(.10)\end{array}$ & $\begin{array}{c}-1.02 * * * \\
(.10)\end{array}$ \\
\hline \multicolumn{4}{|l|}{ Race } \\
\hline Black & $\begin{array}{c}.96 * * * \\
(.17)\end{array}$ & $\begin{array}{c}.70 * * * \\
(.15)\end{array}$ & $\begin{array}{c}.92 * * * \\
(.18)\end{array}$ \\
\hline Asian & $\begin{array}{c}.28 \\
(.23)\end{array}$ & $\begin{array}{l}.51 * \\
(.22)\end{array}$ & $\begin{array}{l}.11 \\
(.23)\end{array}$ \\
\hline Native American & $\begin{array}{l}.31 \\
(.56)\end{array}$ & $\begin{array}{c}.29 \\
(.59)\end{array}$ & $\begin{array}{l}1.5^{*} \\
(.70)\end{array}$ \\
\hline Hispanic & $\begin{array}{c}.87 * * * \\
(.15)\end{array}$ & $\begin{array}{c}.49 * * * \\
(.14)\end{array}$ & $\begin{array}{l}.37 * * \\
(.14)\end{array}$ \\
\hline Other & $\begin{array}{c}.27 \\
(.20)\end{array}$ & $\begin{array}{l}.41 * \\
(.20)\end{array}$ & $\begin{array}{l}.59 * * \\
(.22)\end{array}$ \\
\hline \multicolumn{4}{|l|}{ Sex } \\
\hline Female & $\begin{array}{c}.13 \\
(-.03)\end{array}$ & $\begin{array}{c}.01 \\
(.08)\end{array}$ & $\begin{array}{l}.001 \\
(.08)\end{array}$ \\
\hline Income & $\begin{array}{c}-.03 * * * \\
(.005)\end{array}$ & $\begin{array}{c}-.03 * * * \\
(.005)\end{array}$ & $\begin{array}{c}-.01 \\
(.005)\end{array}$ \\
\hline $\mathrm{N}$ & 2,641 & 2,641 & 2,641 \\
\hline Pseudo $\mathrm{R}^{2}$ & 0.11 & 0.14 & 0.11 \\
\hline \multicolumn{4}{|c|}{$\begin{array}{l}\text { Note: }{ }^{*} \mathrm{p}<0.05, * * \mathrm{p}<0.01, * * * \mathrm{p}<0.001, \text { two-tailed test; VIF scores indicate no serious } \\
\text { multicollinearity issues; Ordered Logit passes Brant test of Parallel Regression Assumption. } \\
\text { Millennials are the base category for Generations, Moderates are the base category for } \\
\text { Ideology, and White is the base category for race. }\end{array}$} \\
\hline
\end{tabular}




\section{CHAPTER III: ATTITUDES TOWARDS POLITICAL INSTITUTIONS}

Early social scientists, such as Mannheim and Ryder, have already demonstrated the importance of studying generations within social science. Later inclusions of generational differences, such as the studies conducted by Strauss and Howe, for example, have shown how generation may influence individual values. It is imperative, however, to assess the methods by which individual values ultimately influence institutions. Riker states that "people whose values and tastes are influential live in a world of conventions about language and values themselves. These conventions are then in turn condensed into institutions, which are simply rules about behavior, especially decision making" (1980). Riker's description of institutions seems cyclical in a sense. People influence the development of institutions, which in turn govern the behavior and values of people, which can then alter the development of later institutions. This cycle is why generational perceptions of institutions are significant to study. An older generation may develop the institutions in a manner that seems appropriate to them, which will inherently guide the behavior of younger generations; however, as the younger generations become more prominent in society, they have the ability to alter the future progression of institutions. These may be different than younger generations that follow them.

Institutions are imperative for understanding collectivism because of their role within human interaction. Moe asserts that self-serving, opportunistic individuals can approach collective-action problems through institutions (2005). The political institutions that create the American government, for example, are a form of bureaucracy that are created through collective choice. Rules that are established by the powerful people within the institutions are projected to everyone within the society. Younger generations are consequently subjected to the rules of the 
older generations. If one generation distrusts the institutions more than another, it is possible that they view the collective nature of the institutions more negatively.

The cyclical development as described by Riker and the collective problem-solving as described by Moe are why attitudes towards institutions are important to observe in a study about generational differences in political values. A discussion of generational differences in attitudes towards political institutions may elucidate some of the ways in which values are created and shaped over a set period of time. Public opinion of American political institutions adds to a conversation about collectivist values because of the nature of the institutions. A government institution with more strength and authority is, by nature, collectively oriented as a result of the powers granted to the institutions by the citizens. Consequently, a population's trust in their government and its institutions may be operationalized as a way to measure the levels of collectivism within a population. An investigation of American citizens' attitudes towards political institutions may highlight another side of the collectivism discussion.

\section{Research Methodology}

In a democracy, political institutions are a manifestation of the powers that citizens have granted their government. A citizen who trusts their government is therefore demonstrating faith in the execution of those powers that the citizens have granted to their institutions. Political institutions within a government execute the collective tasks that the people have assigned to them in their inception. As a result, a citizen who is more collectively-oriented should have higher levels of trust in their government to do what is right.

The dependent variable for this study is a measure of respondents' trust in the government to do what is right. The question asked "How often do you trust the government to 
do what is right?" It is coded in an ordinal scale. The variable was recoded so that "Never" is coded as 1 , "Some of the time" is coded as 2, "About half of the time" is coded as 3, "Most of the time" is coded as 4, and "Always" is coded as 5. The independent variables are the same as the first model: generations, political ideology, race, and income. Those variables are coded in the same way as the first model. Political ideology in this model would potentially affect respondents because someone with a liberal ideology in American politics would likely be more trusting of the federal government, while someone with a conservative ideology would likely be less trusting of the federal government. A liberal perception of the federal government may be more positive because they are more likely to identify the role of the government as a safety net. Conservatives, on the other hand, are likely not as trusting in the federal government because they favor smaller government or government that is not centralized and more in the states' control.

\section{Analysis}

The results of the regression can be found below in Table 3 . The only generation that is statistically significant in comparison to Millennials is the Silent Generation at a 0.05 level. This indicates that the Silent Generation trusts the federal government more than the Millennial Generation. Both liberals and conservatives are statistically significant at a 0.001 level in comparison to moderates. This is potentially due to the ideological differences in overall opinion of the role of government. Black and Hispanic respondents are statistically significant at a 0.001 level in comparison to Whites, but income is not statistically significant in this model.

The model indicates that there is a minimal difference in collectivist attitudes in terms of political institutions. The oldest generation is significantly different than the youngest generation 
in their collectivist attitudes through political institutions. The model shows that the Silent Generation is more collective in terms of institutions because they are more likely to trust that the government, which is a collective problem-solver, will do what is right and expected of them.

This model offers some support for two of the three competing theories. The MacManus study indicates that older generations are more collective because of a need for more resources, which is somewhat supported by this model through the significance of the Silent Generation in comparison to Millennials. The Wilson and Banfield theory suggests that socioeconomic and sociodemographic status are more influential than generational differences, and that theory is partially supported through the statistical significance of race, but evidence to support the socioeconomic influence is lacking. The model fails to show support for the Strauss and Howe generational theory as well. In order to show support for that theory, the Silent Generation and Millennials would have to show similar levels in trust for the government, while Generation X and the Baby Boomers would show lower levels of trust. The theory suggests that Millennials and the Silent Generation should support stronger political institutions to overcome their generational crises, but this model shows that only the Silent Generation does. Generation is thus shown to have a minimal effect on trust towards the federal government, and therefore has a minimal effect on levels of collectivism through political institutions. 
Table 3

Linear Regression Measuring Effects on Trust towards Political Institutions

\section{Trust in Government}

\begin{tabular}{|c|c|}
\hline \multicolumn{2}{|l|}{ Generations } \\
\hline Generation X & $\begin{array}{l}-.02 \\
(.04)\end{array}$ \\
\hline Baby Boomers & $\begin{array}{c}.04 \\
(.04)\end{array}$ \\
\hline Silent Generation & $\begin{array}{l}.13^{*} \\
(.06)\end{array}$ \\
\hline \multicolumn{2}{|l|}{ Ideology } \\
\hline Liberal & $\begin{array}{c}17 * * * \\
(.10)\end{array}$ \\
\hline Conservative & $\begin{array}{c}-.30 * * * \\
(.04)\end{array}$ \\
\hline \multicolumn{2}{|l|}{ Race } \\
\hline Black & $\begin{array}{c}.35 * * * \\
(.06)\end{array}$ \\
\hline Asian & $\begin{array}{l}.21 * \\
(.09)\end{array}$ \\
\hline Native American & $\begin{array}{c}.21 \\
(.24)\end{array}$ \\
\hline Hispanic & $\begin{array}{c}.32 * * * \\
(.06)\end{array}$ \\
\hline Other & $\begin{array}{c}.04 \\
(.09)\end{array}$ \\
\hline \multicolumn{2}{|l|}{ Sex } \\
\hline Female & $\begin{array}{c}.03 \\
(.03)\end{array}$ \\
\hline Income & $\begin{array}{c}.002 \\
(.002)\end{array}$ \\
\hline $\mathrm{N}$ & 2,637 \\
\hline Pseudo $\mathrm{R}^{2}$ & 0.08 \\
\hline \multicolumn{2}{|c|}{$\begin{array}{l}\text { Note: }{ }^{*} \mathrm{p}<0.05, * * \mathrm{p}<0.01, * * * \mathrm{p}<0.001 \text {, two-tailed test; VIF scores indicate no } \\
\text { serious multicollinearity issues; Ordered Logit passes Brant test of Parallel } \\
\text { Regression Assumption. Millennials are the base category for Generations, } \\
\text { Moderates are the base category for Ideology, and White is the base category for } \\
\text { race. }\end{array}$} \\
\hline
\end{tabular}




\section{CHAPTER IV: CONCLUDING REMARKS}

In this study, I test several theories regarding the ways in which generational political attitudes operate as collectivist values. One theory suggests that Millennials and the Silent Generation should be more collective because of their development through specific crises. Another theory suggests that older generations are more collective out of a requirement for more resources and a lower ability to independently gain them. The last theory suggests that there are no generational effects and that the primary determinant is socioeconomic or sociodemographic status. After operationalizing political attitudes towards government spending on social programs, the quantitative results indicate support for Wilson and Banfield's theory which argues that socioeconomic status and sociodemographic status are more influential than generational differences. Consequently, I fail to demonstrate support for the Strauss-Howe generational theory and the MacManus conceptualization of generational resource conflict using this data.

An analysis of various models gauging the generational differences of opinion towards political institution indicates that generations are also not significant when defining trust in the federal government. Higher levels of trust indicate more collectivist attitudes. The Silent Generation trusts the federal government more than the other generations and, consequently, may be defined as more collective; however, political ideology and sociodemographic status were also highly influential on trust in the government. As a result, there is some support for the MacManus theory and the Wilson and Banfield theory.

Given the findings of this study, future researchers, politicians, and policymakers may want to consider the lack of generational differences in collectivist values. In order to better understand, predict, and create policies that are relevant to collectivist attitudes or responses, it 
may be imperative to focus on ideology and socioeconomic and sociodemographic differences. This study is unable to identify evidence for any of the competing theories at an international level, which may be helpful in order to identify whether or not global generations as a whole experiences strong generational differences in collectivist political attitudes. It may also assist in stifling a part of the generational conflict that was prevalent across different media sources during the most recent national American election cycle. Further investigation is necessary, but the charges against younger generations as being more self-centered or uninterested in assisting different groups than older generations might be unwarranted in accordance with this study, and thus may serve to reduce generational social conflict in some capacities. 


\section{WORKS CITED}

Beck, Ulrich and Elisabeth Beck-Gernsheim. "Global Generations and the Trap of Methodological Nationalism for a Cosmopolitan Turn in the Sociology of Youth and Generation." European Sociological Review 25.1 (2009): 25-36.

Bond, Michael H., Kwok Leung, and Kwok Choi Wan. "How does Cultural Collectivism Operate?" Journal of Cross-Cultural Psychology 13.2 (1982): 186-200.

Celinska, Katarzyna. "Individualism and Collectivism in America: The Case of Gun Ownership and Attitudes Toward Gun Control." Sociological Perspectives50.2 (2007): 229-47.

Chen, Fang and Stephen G. West. "Measuring Individualism and Collectivism: The Importance of Considering Differential Components, Reference Groups, and Measurement Invariance." Journal of Research in Personality 42.2 (2008): 259-94.

Congressional Budget Office (2017). The 2017 Long-Term Budget Outlook. p.iv.

$<$ https://www.cbo.gov/publication/52480>

"The Generations Defined." Pew Research Center. 2017. Web.

$<$ http://www.pewresearch.org/fact-tank/2015/05/11/millennials-surpass-gen-xers-as-thelargest-generation-in-u-s-labor-force/ft_15-05-11_millennialsdefined/>.

Hui, C. and Harry C. Triandis. "Individualism-Collectivism: "A Study of Cross-Cultural Researchers"." Journal of Cross-Cultural Psychology 17.2 (1986): 225. Periodicals Index Online.

Hui, C., Harry C. Triandis, and Candice Yee. "Cultural Differences in Reward Allocation: Is Collectivism the Explanation?" British Journal of Social Psychology 30.2 (1991): 145-57.

Hui, C. "Measurement of Individualism-Collectivism." Journal of Research in Personality 22.1 (1988): 17-36.

Jennings, M. Kent, Laura Stoker, and Jake Bowers. "Politics Across Generations: Family Transmission Reexamined." The Journal of Politics 71.3 (2009): 782-99.

Ken I. Kim, Hun-Joon Park, and Nori Suzuki. "Reward Allocations in the United States, Japan, and Korea: A Comparison of Individualistic and Collectivistic Cultures." The Academy of Management Journal 33.1 (1990a): 188-98.

Leung, Kwok, and Michael H. Bond. "The Impact of Cultural Collectivism on Reward Allocation." Journal of Personality and Social Psychology 47.4 (1984): 793-804.

MacManus, Susan A. "Taxing and Spending Politics: A Generational Perspective." The Journal of Politics 57.3 (1995): 607-29.

Maniam, Shiva and Samantha Smith. "A wider partisan and ideological gap between younger, older generations.” Pew Research Center. 2017. Web.

$<$ http://www.pewresearch.org/fact-tank/2017/03/20/a-wider-partisan-and-ideological-gapbetween-younger-older-generations/> 
Mannheim, Karl, and Paul Kecskemeti. Essays on the Sociology of Knowledge. London: Routledge \& Kegan Paul, 1952.

Mansfield, Edward D., and Jack Snyder. "Democratic Transitions, Institutional Strength, and War." International Organization 56.2 (2002): 297-337.

McDermott, Gerald A. "Politics, Power, and Institution Building: Bank Crises and Supervision in East Central Europe." Review of International Political Economy14.2 (2007): 220-50.

Moe, Terry M. "Power and Political Institutions." Perspectives on Politics 3.2 (2005): 215-33.

Pigou, A.C. "Real Income and Economic Welfare." Oxford Economic Papers 3.1 (1951): 16-20.

Radcliff, B. "Politics, Markets, and Life Satisfaction: The Political Economy of Human Happiness." American Political Science Review 95.4 (2001): 939-52.

Ram, Rati. "Income, Distribution, and Welfare: An Intercountry Comparison." Economic Development and Cultural Change 41.1 (1992): 141-5.

Riker, William H. "Implications from the Disequilibrium of Majority Rules for the Study of Institutions." American Political Science Review. 74.2 (1980): 432-436.

Ryder, N. B. (1965). The cohort as a concept in the study of social change. American sociological review, 30(6), 483-861. Retrieved from http://www.econis.eu/PPNSET?PPN=484011146.

Sivadas, Eugene, Norman T. Bruvold, and Michelle R. Nelson. "A Reduced Version of the Horizontal and Vertical Individualism and Collectivism Scale: A Four-Country Assessment." Journal of Business Research 61.3 (2008): 201-10.

Sobieszek, Barbara I., and Richard G. Niemi. "Political Socialization." Annual Review of Sociology. 3 (1977): 209-33.

Strauss, William, and Neil Howe. The Fourth Turning: An American Prophecy. 1st ed. United States: Broadway Books, 1997.

The United States Census Bureau. (2017). Millennials Outnumber Baby Boomers and Are Far More Diverse. <https://www.census.gov/newsroom/pree-releases/2015/cb15-113.html

Triandis, Harry C., and Michele J. Gelfand. "Converging Measurement of Horizontal and Vertical Individualism and Collectivism." Journal of Personality and Social Psychology 74.1 (1998): 118-28.

Valentino, Nicholas A. and David O. Sears. "Event-Driven Political Communication and the Preadult Socialization of Partisanship." Political Behavior 20.2 (1998): 127-54. Social Science Premium Collection.

Whittier, Nancy. "Political Generations, Micro-Cohorts, and the Transformation of Social Movements." American Sociological Review 62.5 (1997): 760-78. Periodicals Index Online Segment 04. 
Wilson, James Q. and Edward C. Banfield. "Political Ethos Revisited." The American Political Science Review 65.4 (1971): 1048-62.

Wilson, James Q. and Edward C. Banfield "Public-Regardingness as a Value Premise in Voting Behavior." The American Political Science Review 58.4 (1964): 876-87.

Wolfinger, R. E., \& J.O. Field. (1966). Political ethos and the structure of city government. American Political Science Review, 60(2), 306-326. 